\title{
Entrepreneurial Strategies of Gardening Business in Cabanatuan City, Philippines
}

\author{
Alvin Gino M. Bautista, MBA; Joy N. Savellano, MM-BM
}

College of Management and Business Technology Nueva Ecija University of Science and Technology-Cabanatuan City, Nueva Ecija, Philippines

Received: 01 Dec 2020; Received in revised form: 18 Dec 2020; Accepted: 25 Dec 2020; Available online: 30 Dec 2020

(C2020 The Author(s). Published by Infogain Publication. This is an open access article under the CC BY license

(https://creativecommons.org/licenses/by/4.0/).

\begin{abstract}
Five to six thousand-year before Christ, gardening was in vogue. The importance of gardening is realized by every individual now in the globe. Gardening which was only an art and science in the earlier days has now emerged as a huge industry. With the importance and need of gardening in improving and conserving the environment being strongly felt now, the concept of landscaping and gardening is growing rapidly. Ornamental gardening and landscaping have expanded as a multi-faceted industry encompassing activities such as propagating and rearing ornamental plants, landscaping, production of growing media, pots and other accessories, generating huge employment opportunities and simultaneously promoting activities that would improve the environment (eagri.org). Farming has become the primary source of livelihood for Novo Ecijanos (N.Natividad, 2020) but due to a growing and phenomenal flourishing of gardening business in Cabanatuan City, Nueva Ecija, Philippines, the researchers want to investigate the entrepreneurial strategies used by the owners as the respondents to survive their business and be on the top. This study used a descriptive method of research which is very helpful in interpreting the gathered data in a survey questionnaire answered by 13 selected gardening business owners in the City of Cabanatuan. It was concluded that there are some entrepreneurial strategies often used by the business and some strategies were rarely done by them, that is why pertinent recommendations for the benefit of the business were given by the researchers at the end of the study.
\end{abstract}

Keywords-Gardening Business, Entrepreneur, Strategies, Cabanatuan City, Nueva Ecija.

\section{INTRODUCTION}

Gardening is an art that uses flowers and plants as paint, and the soil and sky as the canvas-Elizabeth Murray. Gardening has become a popular phenomenon these days. Many people turn their interest in planting trees and other ornamental plants that beautify the surroundings and make the environment clean and green. Thus, the gardening business also booms nowadays and many entrepreneurs tried their luck into this, taking advantage of the peoples' phenomenal attention. This kind of business is already existed a long time ago but not just like others, it is not considered a growing business until COVID 19 Pandemic occurs. The market grows from time to time, it is driven by the increasing number of buyers from first-time householders who increased their interest in gardening. Many people are spending a lot of money just to maintain good health and a strong immune system to prevent sickness. (D. Pastorfide 2020) This pandemic helps the people realized the importance of good health through a better environment, that is why planting and gardening businesses are now in the spotlight. Furthermore, gardening became one of the hobbies, an outlet or stress reliever to many during pandemic that resulted to an increase in demand of various plants and other products/services associated to it.

Nueva Ecija, the province of Cabanatuan City is the Rice Granary of the Philippines. This province has a fertile soil wherein plants can grow faster even without proper cultivation, that is why there are some gardening businesses 
established near the national road of this province. Selling beside the road is what we so-called the traditional way of selling and marketing the plant to the people, but now, there is a rare phenomenon where you can see sellers selling their plant products in the internet, and even inside the shopping malls with a shocking price. Setting up a plant nursery or gardening business can be an overwhelming venture, but it can be extremely rewarding if you have a passion for greenery and a firm knowledge of how to grow and cultivate plants. (wikiHow.com, 2020).

There are many gardening businesses in Cabanatuan City, some are new but many were already established because the current owner inherent this kind of business from their parents and relatives. In all kinds of business, strategies are the key factor to grow and be still on the right track even with different competitors. Thus, the researchers wish to study the entrepreneurial strategies of the gardening business in Cabanatuan City and to evaluate the strategies used and performed by the businessmen that help them to be more profitable amidst this pandemic and even afterward.

\section{OBJECTIVES OF THESTUDY}

Business has its own strength and weaknesses, and if the owner did not manage it accordingly the growth of the business will not prosper and the worst is, it might be bankrupted or be closed immediately. To avoid it, entrepreneurial strategies are very necessary.

The study was conducted to evaluate the entrepreneurial strategies of gardening business in Nueva Ecija. Specifically, it sought to answers the following questions:

1. How may the business profile of the respondents be described in terms of:

1.1 Type of Business
1.2 Number of years in the gardening
business
1.3 Type of business ownership
1.4 Number of employees
1.5 Estimated monthly income before
pandemic
1.6 Estimated monthly income during
pandemic

2. Describe the entrepreneurial strategies of the business in different aspects such as:

2.1 Marketing;

2.2 Products and Services;

\subsection{Organization Management}

2.4 Financial Management

3. Problems encountered by the business in their day to day operation.

\section{METHODOLOGY}

The researchers will employ the Descriptive Survey Method of research. According to Zulueta (2010 Survey research) is the most widely used non- experimental type of educational research. It is used in various situations to investigate a large number of different research problems as they occur in the natural setting to determine the status quo of some variables. Surveys are used to measure opinions, attitudes, or achievements.

The study wishes to find out and describe the present profile of the selectedGardening Business in Cabanatuan City, and assess the problems encountered by the business owners/caretakers in their day to day operation. In addition, it seeks to investigate the different entrepreneurial strategies that they performed to overcome problems and maintain a successful operation.

This study used 13Ornamental Gardening Business Owners or Caretakers in the City of Cabanatuan as respondents. They were randomly selected to answer the casual interviews and questionnaire interpreted by the researchers. The data gathered were used only for the study and treated with supremeprivacy.

After all the data needed were gathered, the frequencies of answers in each question were tallied and their percentage was obtained. The Frequency, percentage, weighted mean, and mode of their answers were calculated in order to obtain its verbal interpretation.

The hereunder scale with its corresponding description was used as a guide in interpreting the response to the items.

Table 1: Scoring Method

\begin{tabular}{|c|c|c|}
\hline SCALE & WEIGHT & $\begin{array}{c}\text { VERBAL } \\
\text { INTERPRETATION }\end{array}$ \\
\hline 4 & $3.26-4.00$ & ALWAYS \\
\hline 3 & $2.51-3.25$ & OFTEN \\
\hline 2 & $1.76-2.50$ & RARELY \\
\hline 1 & $1.00-1.75$ & NEVER \\
\hline
\end{tabular}




\section{RESULTS AND DISCUSSION}

According to the result of the survey conducted with the 13Gardening Business Owner or Caretakers in the City of Cabanatuan as respondents, the following results were:

\section{PROFILE OF THE RESPONDENTS BUSINESS}

It was noted that out of 13 respondents, the majority or 10 are sole proprietorships, and the remaining which is 3 isa partnership.

Five (5) from 13 businesses started2 years ago, the other 5 businesses started 3 to 7 years ago, and the remaining 3 started more than 10 years ago.

Most of the respondents are renting their gardening business location, they were 8 out of 13 respondents and the remaining 5 garden locations are owned by the entrepreneurs.
The survey also revealed that this kind of business can be managed and run by thefamily members alone, employees were needed only if necessary, thus, 9 of the respondents answered they employ only 1-2 individuals as helper or assistant and the rest employed 3 or more.

With regard to the monthly income before COVID 19 pandemic, 4 of the respondents answered they had an income of 0-P5,000, 5 businesses had P5,0001-P10,000, 2 businesses had P10,0001-P20,000, and the remaining 2 had P20,001 and above. However, during COVID 19 pandemic up to the present, their sales increases by $20 \%$ and still growing, this is due to the responsiveness of the people about the importance of a healthy environment as well as the increase in the number of individuals who made gardening and planting as their new hobby.

Table 2 Entrepreneurial Strategies Used by Gardening Business

\begin{tabular}{|c|c|c|}
\hline Factors & $\mathbf{W M}$ & VI \\
\hline \multicolumn{3}{|l|}{ Marketing } \\
\hline $\begin{array}{l}\text { The business used prints, commercials, or social media as a form of advertisement and } \\
\text { online selling. }\end{array}$ & 2.23 & Rarely \\
\hline The business gives promotion like discount and freebie to the customers. & 3.54 & Always \\
\hline $\begin{array}{l}\text { The owner is using a focus strategy by selling products cheapest offering than other } \\
\text { competitors. }\end{array}$ & 2.38 & Rarely \\
\hline $\begin{array}{l}\text { The owner is using a differential strategy by selling products higher offering but high } \\
\text { quality than other competitors. }\end{array}$ & 2.85 & Often \\
\hline The business is using suggestive selling to help the customer & 2.92 & Often \\
\hline General Weighted Mean & 2.78 & Often \\
\hline \multicolumn{3}{|l|}{ Product and Services } \\
\hline $\begin{array}{l}\text { The business considers product positioning wherein the in-demand items are place in the } \\
\text { front. }\end{array}$ & 2.85 & Often \\
\hline Use private labeling or applying brand name. & 1.77 & Rarely \\
\hline Modify or Innovate the products and services. & 2.77 & Often \\
\hline Set strategic goals to motivate and inspire performance. & 2.62 & Often \\
\hline Make strategic planning in selling products and services. & 2.46 & Rarely \\
\hline General Weighted Average & 2.49 & Rarely \\
\hline \multicolumn{3}{|l|}{ Organization Management } \\
\hline The owner gives a bonus and incentives to their employees. & 2.08 & Rarely \\
\hline The employer gives necessary safety and protection measures to their e & 2.62 & Often \\
\hline
\end{tabular}




\begin{tabular}{|c|c|c|}
\hline The employer provides motivation such rewards and other intrinsic motivation. & 2.00 & Rarely \\
\hline The owner attend seminars or training to add new information about gardening. & 2.46 & Rarely \\
\hline The owner give trust to the employees for them not to leave the organization. & 2.15 & Rarely \\
\hline General Weighted Average & 2.26 & Rarely \\
\hline \multicolumn{3}{|l|}{ Financial Management } \\
\hline The business has a monthly income kept on their own house & 3.15 & Often \\
\hline The business deposit their sales and income in the bank. & 1.92 & Rarely \\
\hline $\begin{array}{l}\text { The business accepts E-Payment such as GCash, Paypal, Pay Maya, and the like, other } \\
\text { than cash. }\end{array}$ & 1.46 & Never \\
\hline The business use checks and bank transfer in paying the supplier. & 1.77 & Rarely \\
\hline The owner uses the sales and income of the business for personal use. & 3.08 & Often \\
\hline General Weighted Mean & 2.27 & Rarely \\
\hline
\end{tabular}

Moreover, the problems encountered by gardening business owners are as follows:

1. Pest and plant diseases

2. Water during dry season

3. Over supply of water during rainy season

4. Weeds

5. Lack of buyers

\section{CONCLUSION AND RECOMMENDATIONS}

Based on the aforementioned outcome of the research study the following conclusion and recommendations were drawn by the researchers:

1. With regards to the profile of the business, this kind of business does not need a high capital because sole proprietorship and partnership investors can start up one. The researchers also conclude that the gardening business is good because according to the survey conducted, there were businesses that were established 10 years ago and still operating up successfully until now.One of their advantages is the fact that they are not renting their location. Rental fees can add up to their expenses instead of adding to their net income. If someone wants to start a gardening business, they can use the help of their family members instead of hiring an employee, or get an on-call employee if necessary, like a landscaper. Furthermore, it can be concluded that due to COVID 19 pandemic, the sales of the gardening business increased and continue increasing until now.
2. The main objective of this study is to assess the entrepreneurial strategies used by gardening businesses in the City of Cabanatuan. Thus, based on the survey conducted, the researchers conclude the following:

2.1 Marketing Strategyrefers to a business's overall game plan for reaching prospective consumers and turning them into customers of the products or services the business provides (A. Barone 2020). Based on the data in Table 2, the gardening business in the City of Cabanatuan hasrarely used prints or commercial, for advertisement. Some of them have a Facebook Page Accountand other social media page where they promote their products, but not all of them. To gain customers, one of the most common marketing strategies is giving discounts and freebies to the customers, with this, the answer of the respondents has a weighted mean of 3.54 which has a verbal interpretation of Always. The researcher easily concludes that this strategy was constantly used by all the respondents. Also, Focus Strategy is the way of selling the products at the lowest prices than the competitors, is Rarely done by the respondents. The reason behind this is, they are not adding a high mark up and they are much aware of giving discounts and freebies than using the focus strategy. However, they Often use the Differential Strategy wherein they are selling their products in higher offering but high quality than other competitors. The researchers conclude that the gardening business produces or sells quality plants that can effortlessly transfer from their nursery to the buyer's home that can surely will not easily weather. The researcher concludes also that the respondents used another marketing strategy which is Suggestive Selling 
wherein they introduce another product in exchange for the unavailable one or as another good option to buy. Based on the survey conducted, it has a weighted mean of 2.85 with a verbal interpretation of Often. With a general weighted average of 2.78 with a verbal interpretation of Often, the researcher concludes that Marketing Strategy was practiced by the respondents. However, the researcher suggests to study more about other marketing strategies to make their business more appealing, attractive, and innovative which will surely maintain customers' loyalty, repeat purchase and attract more new customers that will resulted to a more or increase income.

2.2 Product and Services Strategy deals with the number and diversity of products, product innovations, product scope, and product design. (I.Jayant, 2014). The strategies like Product Positioning wherein the in-demand items are placed in the front, Product Innovation or development of new products, and Setting of Goals to motivate the performance that will produce good product and services are Often used by the respondents. The researchers suggest to continue using these strategies for the benefit of the business. Thus, Private Labeling or applying their name to the product or with their own branding, and Strategic Planningwas Rarely done by the business, with this, the researchers recommends to try doing strategic planning. There are different books and articles in the internet that teaches courses in strategic planning like coursera.org, imd.org, and sgs.ph. Having a general weighted average of 2.49 with a verbal interpretation of Rarely, the researchers recommend to use or add strategies in their products and services by studying or reading articles on the website enumerated above.

2.3 Organization Management Strategy is the sum of the actions a company intends to take to achieve long-term goals. Also, top management creates the larger organizational strategy, while middle and lower management adopt goals and plans to fulfill the overall strategy step by step. (S.Johnson 2019). Therefore, this is a joint cooperation of the whole organization to attain their common goal for the benefit of the business. Based on the survey conducted and recorded in Table 2, the researchers conclude that this is the strategy that is not prioritized by the respondents. (a) Giving Bonus or incentives to the employees to keep their trust in the business, or (b) Giving Intrinsic Motivation because, time and again, researchers have found that people with high intrinsic motivation for example, (c) Giving the Employee Trust, to make them driven by internal rewards and satisfaction, perform much better than people offered high extrinsic motivation or external rewards (viGlobal.com 2018). The owner (d) Attend Seminars or Training to add new information about gardening, these strategies are Rarely used by the respondents. Having a general weighted average of 2.26 and a verbal interpretation of Rarely, the researchers recommend to do and adopt these strategies because it can give a positive effect not only on the employees but also on the organization itself. However, the employer Often gives necessary safety and protection measures to their employee to avoid unnecessary circumstances which the researcher recommends to continue.

2.4 Financial Management Strategy is an approach used for managing the finances of a company to meet its strategic goals (corporatefinanceinstitute.com). The researchers noted that some of the Financial Management Strategies like Accepting E-Payment or Electronic Payment like Pay Maya, Paypal, G Cash were not or Never use by the respondents. The researchers recommend this strategy because it is important nowadays to avoid the use of physical money which is prone to counterfeit, and theft and also to avoid the possible spread of the corona virus. Also, the Usage of Checks and Bank Transfer in depositing their sales and income was Rarely done by the respondents, that is why the researchers highly propose to deposit their sales and income on a regular basis, and use the service of the banks like savings, checking, other wire transfer transactions. Having a bank account is also a good strategy because banks can help them grow and expand their business operations by providing loans.Furthermore, the use of bank services and not keeping the sales or income of the business at their home makes the owners avoid spending the money of the business for personal use.

3. With regards to the problems encountered by gardening business owners the researchers' recommendations are as follows:

Prevent Pest and Plant Diseases with Good Gardening Practices. According to Colleen Vanderlinden 2020, Prevention is much easier than treatment. To avoid it, follow good sanitation practices, fertilize to keep plants healthy, before accepting from the suppliers, inspect plants for diseases to avoid infecting other plants, allow the soil to warm before planting, water in the morning, and mulch to maintain soil moisture and keeping weeds down, provide good air circulation, watch out for insect pests, and remove diseased stems and foliage immediately. If the gardening business 
owner follows these, surely it will lessen or eliminate the pests and plant disease.

Due to climate change, the gardening business is suffering from an undersupply of water during the dry season, with this, the researchers recommend to have a deep well for watering the plant during dry season, and do mulching. When quality mulches cover the soil, they prevent the loss of soil moisture as by reducing evaporation. They increase water infiltration while also preventing soil compaction due to dryness. Mulches also control the germination and growth of weeds and inhibit the spread of soil-borne diseases. These mulches can also serve as insulation to stabilize the soil temperature and protect the roots from extreme temperatures during the summer or rainy season. (JK Cooper, 2017). On the other hand, during the rainy season where an oversupply of water is unnecessary, the researcher recommends the use of the net or netting the garden, and have a properly constructed canal for the right flow of unwanted water.

Continuous research and development in the field of entrepreneurial strategies in the gardening business is highly encourage. Therefore, new and improved discoveries on strategies, inputs, and production methods can contribute to the gardening business's future development.

\section{REFERENCES}

[1] Development of e Courses for B.Sc.(Agriculture), Tamil Nadu Agricultural University, http://eagri.org/eagri50/HORT281/pdf/lec33.pdf

[2] NESTOR C. NATIVIDAD; ISAGANI F. PASCUA; JOEY A. DE LA CRUZ. "Farm Business Operations in Bongabon, Philippines: Status and Challenges." Volume. 5 Issue. 11, November - 2020, International Journal of Innovative Science and Research Technology (IJISRT), www.ijisrt.com. ISSN 2456-2165, PP :- 847-851.

[3] DAVE M. PASTORFIDE; DANILO D. PASTORFIDE. "Insurance Value in the 21st Century: A Perspective of the Educators in the State University and Colleges." Volume. 5 Issue. 11, November - 2020, International Journal of Innovative Science and Research Technology (IJISRT), www.ijisrt.com. ISSN - 2456-2165, PP :- 455-461.

[4] Patrick Millington Synge et all, Gardening, Encyclopædia Britannica, March 26, 2020, https://www.britannica.com/science/gardening

[5] Ellaine Grace L. Nagpala, "Landscaping" Bar Digest, January-March 2007, Volume 9 Issue No. 1 Landscaping Business - How To Landscape With Ornamentals (pinoybisnes.com)

[6] Noel Greene, Why Strategy is Important, evolve. https://evolve.ie/q-and-a/business-strategy-important/
[7] Adam Barone, Investopedia, Marketing Strategy, April 2020 Marketing Strategy Definition (investopedia.com)

[8] Isaac Jayant, Product and Services Strategies, Slideshare, January 21, 2014, Product and Services Strategies (slideshare.net)

[9] Sophie Johnson, Chron, What Is the Meaning of Organizational Strategy? March 8, 2019, What Is the Meaning of Organizational Strategy? (chron.com)

[10] Vi Global, Intrinsic motivation: 3 things that motivate employees more than money, December 11, 2018, https://www.viglobal.com/

[11] Colleen Vanderlinden, Prevent Plant Diseases with Good Gardening Practices, the spruce, September 17, 2020, www.thespruce.com

[12] JK Cooper Tree Services, What is Mulching, February 17, 2017, www.jkcooper.com.au 